\title{
The use of video to improve students'writing of Procedure text at the second grade of SMPN 8 Bandarlampung
}

\author{
Elisa Rakhmawati ${ }^{1}$,Ujang Suparman ${ }^{2}$, Gede Eka Putrawan $^{3}$ \\ Universitas Lampung,Jl.Prof.Dr. Soemantri BojonegoroNo.1Bandar Lampung, Indonesia ${ }^{123}$ \\ ${ }^{1}$ Correspondence:elisarakhmawati@gmail.com/Phone081573520623
}

\begin{abstract}
The aim of this research was to find out whether or not there was significant improvement $\mathrm{o}$ students' procedure text writing ability after the implementation of video as media. This research was also intended to investigate students" perception with regard to interest, challenge, choice and enjoyment of the implementation of video as media in language learning. This research was conducted through both quantitative and qualitative approach. A total of 29 eighth graders of SMP Negeri 8 Bandarlampung took part in the current study. The instruments used inthis research writing test (pre- and post-test) and questionnaire. The result showed that studentse average score in the pre-test was 53.93 and in the post-test was 59.13 in which the gain scorewas5.20.The result of the Paired Sample t-test confirmed the hypothesis that there was significant improvement in studentse procedure text writing ability at the $p<0.05, p=.000$. Theresults of the questionnaire for the second research question also showed that this learningmedium helps students increase their interest, as well as provides their learning experience with challenge, choice and enjoyment.
\end{abstract}

\section{Keywords:video,writing,proceduretext,students'perception}

\section{INTRODUCTION}

In educational environment in Indonesia the studentse goal to learn English in 2013 Curriculumis to be able to communicate in English in written and oral forms (Permendikbud No. 64, 2013).There are actually two categories of English skills: receptive and productive. Harmer (2001)states that receptive skills include listening and reading since the learners are not required toproduce languageand justreceiveand understand it. On the otherhand, Nunan (2003) statesthat productive skills include speaking and writing since the learners should be able to producelanguage as an outcome after learning the language. The students thus should learn those fourskillsofEnglishnamely, listening, speaking, readingandwriting.

Writing is not a simple matter of how someone trying to transcribing their thoughts or ideas intowriting symbols because it requires harder thinking process to generate ideas. Richard (2002)supports this idea that writing is the most difficult skill for second language learners to master.Writing was also becomes one of the English skills learnt in junior high school and there areseveral genres of writing that should be learned namely, narrative, descriptive, procedure andrecounttext.

Procedure text is designed instructions to direct, inform and explain how something is achievedthrough a sequence of steps (Barwick, 1999). The purpose of the text is to provide instructionsfor making something, doing something or getting somewhere. Thus, it is important for the learners to make a good procedure text to avoid misunderstandings. Barwick (1999) adds that the successful communication of procedure depends on the person who is communicating having the skills to pass it on accurately.

However based on researcher's pre-observation in SMPN 8 Bandar Lampung, 7 out of10students who were chosen to represent one whole class of VIIIC were making many errors 
intheir procedure text writing. Learning media that might not be suitable for students could be one of so many issues that caused this problem.

Based on the explanation above there are a lot of media that can be applied in learning activity as a solution for this problem. One of the media that can be applied is by using short video in learning writing of procedure text.

Media can be classified into three types namely visual, audio, and audio-visual media (Ariani\&Haryanto, 2010). There are many kinds of media that in this era every teacher is required to beable to integrate their classroom with the use of media as a form of technology. Video is one oftechnologies that can be used as media for teaching a procedure text. Video provides constant movement of sophisticated images, moving pictures, animated pictures, or moving text accompanied by audio or sound effects. On its advantage, many educators have chosen to use video slowly for viewing comprehension which is a process of comprehending visual and verbalmessages (Reyes, 2005). That is to say, by viewing a video we would likely feel motivated tocomprehend the visual and verbal message inside it. A research also has been conducted by Akmala (2011) to find out students ${ }^{\text {ee }}$ improvement in writing of narrative text by using video. The result of her study shows that video can improve students' ability to write narrative textbecause this media can attract and grow students "e motivation in learning that they can learn better. Thus this media can give a good impact on their achievement in learning activity.

Indrasari (2010) found out that using short video in teaching writing could improve the students ${ }^{\text {ee }}$ attitude toward writing during the teaching learning process like students were able to show more motivation to join the writing class.

Referring to the explanation above, this research tried to apply short video as media in teaching writing of procedure text in Junior High School. Therefore, the objectives of this research are (1) to find out whether there is any significant improvement of students ${ }^{\text {ee }}$ writing of proceduretext after the implementation of the video as media in language teaching, and (2) to investigate the students "perception with regard of interest, challenge, choice and enjoyment of the implementation of video as media in language learning.

\section{METHODS}

\section{Participants}

The population in this research was the eighth grade of SMPN 8 Bandar Lampung in academicperiod 2019/2020. One class was chosen as sample and it was chosen randomly to avoid thesubjectivity of the research (Setiyadi, 2006). Thus the sample of this research was the students in class $8 \mathrm{C}$ consist of 29 students with12 females and 17 males.

\section{Instruments}

Writing tests were used as the instrument to find out the increase of students ${ }^{\text {ee }}$ writing skill afterthe implementation of video as media in language learning. Writing test as instrument in thisstudy plays a key role in determining whether the objectives of teaching writing can be achieved or not (Suparman, 2016). A questionnaire was used to investigate students ${ }^{\text {ee }}$ perception with regard to interest, challenge, choice and enjoyment after the implementation of video as media in language learning. 


\section{DataAnalysis}

The quantitative data that has been obtained then was analyzed through the steps as follows: (1)Tabulating the results of the tests and calculating the means of pre- and post-test scores. (2)Drawing conclusion from the tabulated results of the tests given, that is by statistically analyzing the data by using Paired Sample t-test to show the differences between pro- and posttests to answer the hypothesis. The qualitative data was analyzed through steps as follows: (1) Tabulating the students "answer on the questionnaire. (2) Determining the coefficient of reproducibility and scalability. (3) Using descriptive analysis to analyze the data.

\section{RESULTS AND DISCUSSIONS}

\section{Results}

In order to see whether or not the objectives of the research were achieved, the researcher analyzed the result of students "writing on pre-test and post-test which is displayed in Table1.

Table1.Frequency Distribution of Students " Writing Scores Both in the Pre-Test and in Post-Test

\begin{tabular}{|cccccc|}
\hline Score & $\begin{array}{c}\text { Frequency } \\
\text { of } \\
\text { Pre-test }\end{array}$ & Percentage & $\begin{array}{c}\text { Frequency } \\
\text { of } \\
\text { Post-test }\end{array}$ & Percentage & Category \\
\hline $45-49$ & 6 & $20.69 \%$ & 2 & $6.90 \%$ & VeryLow \\
\hline $50-54$ & 10 & $34.48 \%$ & 4 & $13.79 \%$ & Low \\
\hline $55-59$ & 10 & $34.48 \%$ & 11 & $37.93 \%$ & Average \\
\hline $60-64$ & 2 & $6.90 \%$ & 5 & $17.24 \%$ & Good \\
\hline $65-69$ & 1 & $3.45 \%$ & 6 & $20.69 \%$ & High \\
\hline $70-74$ & 0 & $0.00 \%$ & 1 & $3.45 \%$ & VeryHigh \\
\hline Total & 29 & $100 \%$ & 29 & $100 \%$ & \\
\hline Mean & 53.931 & & 59.1379 & & \\
\hline Gain & & 5.2069 & & & \\
\hline
\end{tabular}

Table 1 shows that the students ${ }^{\text {ee }}$ writing score increased after the implementation of video asmedia. It can be seen from the differences of mean score gained by the students before and afterthe treatment was given. Besides, the data from Table 1 also showed that the frequency ofstudents getting score lower than 50-54 was decreasing on the post-test. Thus it couldbeconcluded that this media did improve students' procedure text comprehension ability whichlead them to have a better achievement in writing this particular topic. the mean of the post-testwhich was higher than the pretest. The calculation of the mean score showed that the mean of students' pre-test score was increasing as much as 5.206 on the post-test.

However to prove that the hypotheses proposed by the researcher was accepted, the researcher took Paired Sample t-test on SPSSver.16 and the result can be seen as follows:

Table2. T-test Resultof Hypotheses Analysis

\begin{tabular}{|cc|}
\hline \multicolumn{3}{|c|}{ PairedDifferences } \\
\hline \multicolumn{4}{c}{$95 \%$ Confidence } \\
Std.De $\quad$ Std. $\quad$ Intervalofthe \\
\end{tabular}




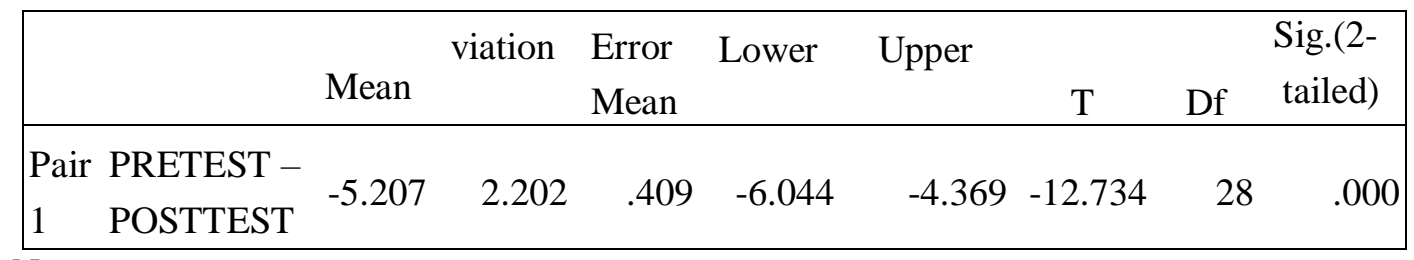

Note:

- Sig.(2-

tailed)is $0.00(<0.05)$ meaningthereissignificantimprovementonmeanscorebetweenPre-

TestandPost-Test.

Table 2 above shows that significance level is lower than $0.05(0.00<0.05)$. It could beconcluded that there is difference in the mean score of the pre-test and post-test. The mean score of both tests are different in the way that the mean score of the post-test is higher than the one on the pre-test, it can be concluded that students ${ }^{\text {ee }}$ writing of procedure text does improve significantly after short video was implemented in teaching writing of procedure text.

The researcher has also calculated the improvement of each aspect of writing after the videos asmedia in teaching writing were implemented. These aspects of writing are adopted from Jacob(1981). The improvement of each aspect of students "writing can be seen as follows:

Table3.The Increaseof Each Aspect of Writing

\begin{tabular}{|ccccccc|}
\hline \multirow{2}{*}{ No. } & \multirow{2}{*}{ Aspects } & \multirow{2}{*}{ Percentages } & \multicolumn{2}{c}{ Mean Score } & \multirow{2}{*}{ Gain } & \multirow{2}{*}{ The Increase(\%) } \\
\cline { 4 - 6 } & & Pre-test & Post-test & & \\
\hline 1 & Content & $30 \%$ & 18.41 & 18.79 & 0.38 & $1.3 \%$ \\
\hline 2 & Organization & $20 \%$ & 11.74 & 13.14 & 1.4 & $7 \%$ \\
\hline 3 & Vocabulary & $20 \%$ & 10.45 & 11.91 & 1.46 & $7.3 \%$ \\
\hline 4 & Grammar & $25 \%$ & 10.6 & 11.93 & 1.33 & $5.32 \%$ \\
\hline 5 & Mechanic & $5 \%$ & 2.76 & 3.4 & 0.64 & $12.8 \%$ \\
\hline
\end{tabular}

Based on the Table 3, each aspect of writing is improve and it can be seen from the differencebetween the mean score of students ${ }^{\text {ee }}$ writing in the pre-test and post-test. However, the aspectthat least improved wascontent and in contrast, the vocabulary aspect improved the most amongst all four other aspects. The result above indicates that the implementation of video asmedia in learning and teaching writing apparently can help the students to be better in writingprocedure text especially in vocabulary aspect. These findings are in line with Harmer (2001)that states one of the advantages of using the video is on the opportunity to see the language.This opportunity enhances the students ${ }^{\text {ee }}$ understanding about the language thus the studentscould gain knowledge about aspects of writing including the vocabulary aspects. However, thestudents were still kind of falling short to increase their ability in aspect of content. Comparingthe students ${ }^{\text {ee }}$ mean scores of pre-test and post-test on Table 3, the students have not showedhuge differences or increase on aspect of content.This finding might be caused by the fact thatit took longer for them to comprehend content of writing from video as they have to watch thevideo until the very end to conclude the result or to resume what the video was about whichcaused nothing new syndrome and poor viewing conditions (Nunan, 2001). Or it might becausedby students ${ }^{\text {ee }}$ lack ofability tointerpretunstatedinformation or inexplicitly showninformation in the video (Suparman 2020a; Suparman 2020b, Suparman 2020c). Nothing newsyndrome and poor viewing conditions have actually been described as the disadvantages 
ofusing video. This is what the researcher believed to be the reason of how the aspect of content in post-test was not showing huge differences from pre-test.

According to the results that have been discussed above, it can be concluded that video can helpthe students to create better procedure text writing. Exposing the students with language inputfrom video would enhance the students" understanding about the language. CanningWilson(2000) supports this idea that the video can act as stimulus or catalyst to help integrate materials or aspects of the language.However, the improvement of aspect content still kind of fallingshort due to how the video caused nothing new syndrome and increasing the possibility of poor viewing conditions. 
In this study, the researcher also investigated the students ${ }^{\text {ee }}$ perception with regard to interest,challenge, choice and enjoyment. Through a questionnaire, the researcher manages to obtain the data. The result of the questionnaire can be seen in the following table:

Table 4. Descriptive Statistics of the Questionnaire

\begin{tabular}{|lrrrrr|}
\hline \multicolumn{1}{|c}{ Dimension } & & Minimum & Maximum & Mean & \multicolumn{1}{c|}{ Std.Deviation } \\
\hline Interest & 29 & 8 & 12 & 10.17 & 1.227 \\
\hline Challenge & 29 & 5 & 8 & 6.62 & .677 \\
\hline Choice & 29 & 5 & 8 & 6.72 & .922 \\
\hline Enjoyment & 29 & 9 & 12 & 10.62 & 1.015 \\
\hline ValidN(listwise) & 29 & & & & \\
\hline
\end{tabular}

From Table 4 above, the mean of score of each aspect of the perception would reflect number ofscale that most of the students had chosen. Thus, since the mean score of each aspect of the perception is heading closer to the maximum points which are 12 for interest andenjoyment,and 8 for challenge and choice it means most of the students are answering the questions on thequestionnaire by choosing the highest scale which is 4 which indicates Totally Agree. It can be concluded that most of students are Totally Agree that this media is interesting, challenging, has proper choice as well as enjoyment in language learning.

\section{Discussions}

Given the condition of students ${ }^{\text {ee }}$ procedure text writing in the pre-test the researcher concludesthat most of the students were not able to properly create their own procedure text writing. From the pre-test result, their procedure text writing still lack of proper grammar, vocabulary, mechanic, content, and organization. There were not many variations of vocabulary that the students used in their procedure text writing which indicates that the students had limited amount of vocabulary to support their writing. The students were also unable to form grammatically correct sentence. In mechanic, the students still misplaced some capital letters byusing them in the middle of the words. The students had understand general concept of content and organization in writing but still falling short in making sure the content and organization that they used were appropriate.

After the videos were implemented in the class, the students showed some improvements. Theymanaged to create longer sentence as they learn many new vocabulary from the video. Thisfinding verify theory from Canning-Wilson (2000) that video offers contextual support and/orhelps learner to visualize words as well as meaning. The words were visualized in the way thatthe words were corresponding to the narrator's gestures and it is useful to help the students to observe and understand the meaning of the word and utterances being said by the narrator.

The sentences created by the students had also become clearer due to the fact that this mediahelped them to understand how to apply grammatically correct sentences. Harmer (2001) statesthat one of the advantages of using the video is on the opportunity to see the language. The statement implies that the students were not only able to hear the language but also to see the 
Language in the way that they were able to correspond the utterances produced by the narrator with what the narrator was doing physically. As the students were watching the video manytimes,they were become aware and know about the grammatical and syntactical patterns thatare used in a procedure thus it helped them to know the grammar that are supposed to be used when they have to do certain things.

The subtitle that were equipped on each video helped the students to avoid misspelling and alsohelping the students to know better about the appropriate mechanic that should be used in asentence.Even though this aspect does not improve directly because of the use of video,Vanderplank (1988) argues that subtitles might have a potential value in helping the learning acquisition process by providing learners with the key to massive quantities of authentic and comprehensible language input.

The aspect of content was also improved since the topic of the video that were used is in the sametopic of the text that the researcher tried to observe which is about procedure. Canningwilson(2000) supports this idea that the video can act as stimulus or catalyst to help integrate materials or aspects of the language. In the video the narrator would narrate the goal and mention whatingredients or materials that should be used along with step that need to be taken in order to achieve the goal.

In organization the students managed to avoid misplace some of the steps that they wrote whichhad become a common problem before this media was implemented. Shams, Khanam and Imtiaz (2001) have also implied that as the learners watch the audio-visual the students wouldcome across new ideas and information which will activate their cognitive thinking and thelearner will at once start processing all these inputs in his mind. The way that the narratornarrated the video sequentially from the start until the video end becomes a good input to make the student understand about the organization of the procedure.

From the explanation above, it can be concluded that this media can significantly improve students' writing of procedure text. The improvement can be seen in each aspect of writing namely content, organization, grammar, vocabulary and content.

Obtaining the data about students" perception with regard to interest, challenge, choice, andenjoyment of the implementation of video as media in teaching and learning would provide aninsight on how this media provides them withinterest, challenge, choice, and enjoyment asthese dimensions are linked to students achievements. The first dimension of this perception isinterest. Apparently the implementation of video as media in the classroom could provide thestudents with motivation to learn, opportunity to generate ideas to write and also provide themwith a better learning experience.Aside from the fact that the short video could help thestudents create better procedure text writing, the video also provides the students with betterlearning experience. These findings are in line with Tassinari (1996) that as the students start tofeel motivated and interested in their work, the students would also start to be more responsible for the learning thus they learned more efficiently.

The second dimension of perception in this study is challenge and how this media could provide challenge during the learning process. Providing the students with challenge is important as the 
lack of challenge might increase the level of boredom in classroom. Gentry, Gable \& Springer (2001) also implied that high expectations and conscious efforts to provide challenges to students more often than their perceived "sometimes" are important consideration. Implementing video in the classroom could encourage the students to try something new. Assisting the learning with challenging tasks and adjusting the task and starting it from the easiest and then gradually increasing the level of difficulties could also be one way to present challenge. By doing this the students would easily keep up with the learning activities without feeling bored because the tasks are too difficult or too easy to be followed. Thus, most of the students find that the implementation of this media fit their ability. In understanding the video, the students might find it challenging as the narrator was a native speaker. Assisting the students to watch the video with subtitle could also be one way to turn this challenge into opportunity tomake them learn the target language. Vanderplank (1988: 272-273) also states that subtitles might have a potential value in helping the learning acquisition process by providing learners with the key to massive quantities of authentic and comprehensible language input.

The third dimension of perception in this study is choice. Providing the students with choice tochoose what video they would like to learn first apparently would encourage them to learn.When they got to choose what video they would like to learn first, the teacher would be able tosee the studentse desire in learning and using that to enhance students ${ }^{\text {ee }}$ learning experience andhelp them to get better achievements in the material that they learned. The second question inthis dimension is related to integrate other choice which the fact that the students would be ableto find and use other video besides from what the teacher showed them. Gentry, Gable \&Springer (2001) indicates that integrating choice is the simplest modification that can be madeby the teacher to increase motivation and learning. Besides, choice is also can be used tohelpthe students to connect them with their interest and eventually increase their motivation to learn.Gentry et al. (2001) then suggest some other meaningful choices that are not too difficult tointegrate namely, choice of types of assignments, group members (or not), order curriculum,specific content, audiences, and relevant homework are other not-so-difficult-tointegrate typesofchoice.

The last dimension of perception in this research is enjoyment. The use of this video in languagelearning apparently could make the students enjoy the learning activities and make the activities in the class become more interesting. Concerning this dimension, it can be said that the enjoyment would likely increase once the students are provided with interest and choice. But with how this media provides the students with appropriate challenge, the students could still feel the enjoyment since they are learning the material through working on tasks that are not too difficult or too easy to be followed. Malone \& Lepper (1987) support this idea that even the increase in challenge might positively affect enjoyment since students often derive satisfaction from appropriate challenge and learning. Thus, it can be implied that the enjoyment also appears to be the result of how this media not only could provide the students with interest and choice but on how this media can also provide an appropriate challenge.

From the questionnaire that had been distributed after the post-test it could be concluded that in general, students found this media sparks their interest to learn the topic, provide them with challenge, offered them with choice as to the opportunity of choosing what video they would like to learn first. The students also view this short video as media that is enjoyable. 


\section{CONCLUSIONS AND SUGGESTIONS}

\section{Conclusion}

In connection with the results ofthe study, the following conclusions can be drawn: (1) Video as media can significantly improve students' writing of procedure text at the second grade of SMPN 8 Bandar lampung. It is proved statistically by taking Paired Sample t-test on SPSS ver.16 in which the result is $\mathrm{p}<0.05, \mathrm{p}=.000$ meaning there was significant improvement in students' procedure text writing after this media was implemented. The aspect that improved the most was vocabulary and the aspect that less improved was content. (2) Most of the students found this media sparks their interest to learn the topic, provide them with challenge, and offered them with choice. They also view this short video as media that is enjoyable.

\section{Suggestions}

Related to some issues that the researcher found during the research, the researcher provides some suggestions as follows: (1) The English teacher should start to consider using this media in classroom to improve students' procedure text writing. The use Freeze-Framing technique could help the students who still have low knowledge in forming words into sentence. (2)The English teacher might want to consider using this media to improve other skills. (3) The English teacher should be able to direct students' attention to learning objective without decreasing their opportunity to enjoy the video. (4) It would be better to use not only questionnaire but also to administer interview or focus group discussion to gain richer and reliable data to support thequalitative data. (5) Thevideos that are going to be implemented in classroom should be reviewed thoroughly in case the content of the video would give bad impact or harm the students. (6) It would be better to use videos that have already equipped with subtitle because making subtitle manually would require a lot of time. (7) The other researchers should try to find out how this media could improve students' writing skill in higher education.

\section{REFERENCES}

Akmala, T. A. (2011). The use of animated film to improve students' ability in writing narrativetext: A classroom action research at the 10th grade of MAN Pemalang. Undergraduatescript.Semarang: English Language Education Department, WalisongoState InstituteforIslamicStudy

Ariani, N.\&. Haryanto, D.(2010). Pembelajaran multimedia di sekolah. Jakarta:PrestasiPustaka.

Barwick, J. (1999). Targeting Text: Recount, Procedure, Exposition, Upper Level. Sydney:BlakeEducation.

Christine, C. W., \& Julie, W.(2000).Practical aspects of using video in the foreign languageclassroom.TheInternetTESLJournal, Vol. VI,No.11, November2000.

Retrievedfromhttp://iteslj.org/Articles/Canning-Video.html 
Gentry, M., \& Gable, R. K. (2001).My Class Activities: A survey instrument to assess students 'perceptionsofInterest, Challenge, ChoiceandEnjoymentintheirclassrooms. Mansf ieldCenter,CT:CreativeLearningPres.

Ghozali,I. (2011). Aplikasianalisis multivariate dengan program SPSS. Semarang: BadanPenerbitUniversitasDiponegoro.

Harmer,J.(2001).Thepracticeofenglishlanguageteaching.Cambridge,UK.PearsonEducationESL. Hatch,E.M.,\&Farhady,H.(1982).Researchdesignandstatisticsforappliedlinguistics.

Mass:NewburyHouse.

Indrasari,N.(2010).Improvingstudents'writingskillofnarrativetextsbyusingshortvideos.

Temanggung:RadenIntanStateIslamicUniversity

Jacobs., Holly, L., Stephen, A., Zingkgraf., Deanne, R., Wormuth, V., Faye, H., Jane, B.,Hughey. (1981). Testing ESL Composition: A practical approach. Rowley: NewburyHousePublishers,Inc.

Malone, T. W., \&Lepper, M.R. (1987) Making learning fun: A taxonomy of intrinsic motivationfor learning. In Snow, RE.and Farr, M.J., Eds., Aptitude, Learning and Instruction III:Conativeandaffectiveprocessanalyses, Erlbaum, êHillsdale.

Nunan, D. (2003). Practical English language teaching. Singapore: McGrawHillPermendikbud,R.I.No.64Tahun2013TentangStandarIsiPendidikanDasardanMenengah. Jakarta:Kemendikbud

Reyes,M.(2005).TeachingTechnologies:Teachingenglishusingvideo.

Retrievedfromhttps://facultystaff.richmond.edu/t

Richard, J., \&Renandya, W. A. (2001).Methodology in Language Teaching:Ananthologyofcurrentpractice.NewYork:CambridgeUniversityPress.

Setiyadi,Ag.Bambang.(2006).Metodologipenelitianuntukpengajaranbahasaasing,pendekatanku antitatifdankualitatif. Yogyakarta:GrahaIlmu.

Shams, A., Khanam, A., \&Imtiaz, S. (2016). The impact of audio-visual aids and graphicorganizer on the writing Skills of ESL learners at AMU +2 Girls. Global Journal ofInterdisciplinarySocialSciences, 5(5),15-36.

Retrievedfromhttps://www.longdom.org/abstract/the-impact-of-audiovisual-aids-andgraphic-organizers-on-the-writing-skills-of-esl-learners-at-amu-2-girls-2689.html.

Suparman,U.2016.PenilaiandalamPembelajaranBahasa.Yogyakarta:GrahaIlmu

Suparman, U.,Ridwan, R. \& Hariri, H. 2020a.Promoting Learning Performance andLearning Outcomes: The Case of an Indonesian School.The Asian EFL Journal, October2020,Volume27,Issue4.1,pp.94-110.https://www.asian-efl-journal.com/monthlyeditions-new/2020-monthly-editions/volume-27-issue-4-1-october-2020/

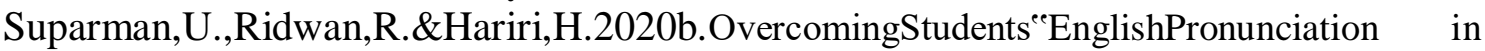
Remote Area, Indonesia.The Asian EFL Journal, October 2020, Volume27, Issue 4.1, pp. 94-110. https://www.asian-efl-journal.com/monthly-editions-new/2020-monthlyeditions/volume-27-issue-4-1-october-2020/

Suparman, U., Hariri, H., Haenila, E.Y., \&Usman, M. 2020c. Completely randomized blockdesign for assessment of the gender and personality effect on reading comprehensionability. JournalofSouthwestJiaotong University,Vol.55 No. 4 Aug.2020,pp.1-14. DOI

: 10.35741/issn.0258-2724.55.4.21.

http://jsju.org/index.php/journal/article/view/666

Tassinari,M.(1996).Hands-onprojectstakestudentsbeyondthebook.SocialStudiesReview.

No.34:16-20 
Vanderplank (1988).The value of teletext sub-titling in language learning.ELT Journal. No. 42:272-281 